\title{
Combustion and Ball Milled Synthesis of Rare Earth Nano-Sized Ceria Powder
}

\author{
Ranjan Sen, Siddhartha Das, Karabi Das
}

Department of Metallurgical and Materials Engineering, Indian Institute of Technology, Kharagpur, India.

Email: ranjansen2001@gmail.com

Received March 29 $9^{\text {th }}, 2011$; revised April 2 $2^{\text {nd }}, 2011$; accepted April 10 $0^{\text {th }}, 2011$.

\begin{abstract}
This paper reports a study on nanocrystalline ceria powder prepared by high energy ball-milling and combustion synthesis methods. The combustion synthesis was carried out using ceric ammonium nitrate as oxidizer and citric acid, glycine or citric acid plus glycine as fuel. The minimum crystallite size of ceria powder is obtained by combustion synthesis of ceric ammonium nitrate and citric acid. The ceria powder produced by combustion synthesis of ceric ammonium nitrate and citric acid and glycine has less agglomeration of particles than other techniques.
\end{abstract}

Keywords: Ceramics, Ball Milling, Combustion Synthesis, Nano-Sized Ceria, X-Ray Diffraction

\section{Introduction}

Now day's different routes such as mechanical alloying, combustion synthesis, plasma forming, explosive forming, electro deposition and sol-gel process are used for producing nano-sized ceramics or metals. Among them, high energy ball milling and combustion synthesis are the most useful techniques for producing nano-sized ceramics and ceramic-composites. The ball milling technique is more environmentally safe than the method of chemical synthesis, producing far less chemical waste [1]. A number of nanostructured metal oxides and their solid solutions such as $\mathrm{Fe}_{2} \mathrm{O}_{3}-\mathrm{SnO}_{2}$ [2], $\mathrm{ZrO}_{2}-\mathrm{Fe}_{2} \mathrm{O}_{3}$ [3], $\mathrm{TiO}_{2}$ $\mathrm{Fe}_{2} \mathrm{O}_{3}$ [4], $\mathrm{TiO}_{2}-\mathrm{WO}_{3}$ [5], $\mathrm{Pb}\left(\mathrm{Zr}_{0.52} \mathrm{Ti}_{0.48}\right) \mathrm{O}_{3}$ [6], $\mathrm{SrTiO}_{3}$ [7], $\mathrm{SiC}, \mathrm{Si}_{3} \mathrm{~N}_{4}$ and quartz $\left(\mathrm{SiO}_{2}\right)$ powders [8] have been prepared by using high-energy ball milling method. Moore et al. [9] reported that compared with conventional ceramic processing, the most obvious advantages of combustion synthesis are primarily the generation of a high reaction temperature which can volatilize low boiling point impurities and therefore, result in higher purity products, the short exothermic reaction times result in low operating and processing costs, the high thermal gradients and rapid cooling rates can give rise to new non-equilibrium or metastable phases and inorganic materials can be synthesized and consolidated into a final product in one step by utilizing the chemical energy of the reactants. In our present study nano-sized ceria powder has been synthesized by different techniques including high energy ball milling technique and combustion synthesis. In the ball milling technique the nano-sized ceria particles have been produced after $10 \mathrm{~h}$ milling of as-received ceria powders. Combustion synthesis has been carried out by using 1) ceric ammonium nitrate (CAN) $\left(\left(\mathrm{NH}_{4}\right)_{2} \mathrm{Ce}\left(\mathrm{NO}_{3}\right)_{6}\right)$ and glycine $\left(\mathrm{NH}_{2} \mathrm{CH}_{2} \mathrm{COOH}\right)$ 2) $\mathrm{CAN}$ and citric acid $\left(\mathrm{C}_{6} \mathrm{H}_{8} \mathrm{O}_{7}\right)$ and 3) $\mathrm{CAN}$, glycine $\left(\mathrm{NH}_{2}-\mathrm{CH}_{2} \mathrm{COOH}\right)$ and citric acid, this process is also called mixed fuel technique.

The nano-sized ceria powders produced by different routes have been characterized by the X-ray diffraction (XRD), field emission scanning electron microscopy (FESEM) and high resolution transmission electron microscopy (HRTEM).

\section{Experimental Procedure}

\subsection{Synthesis of Ceria Powders by High Energy Ball Milling Technique}

High energy ball milling (HEBM) of ceria powder (Alfa Aecer, 99.5\%) is carried out using cemented tungsten carbide milling media with toluene as the process control agent. The mill is operated at a speed of $300 \mathrm{rpm}$ and the ball to powder ratio is 10: 1 . The $10 \mathrm{~h}$ ball milled powder is washed with distilled water and then with ethyl alcohol followed by drying.

\subsection{Synthesis of Ceria Powders by Combustion Synthesis Techniques}

Nano-sized ceria single crystals are synthesized by the 
combustion of aqueous solutions containing metal nitrate and fuel. Three different fuels i.e., glycine, citric acid or glycine and citric acid have been used in the present study.

Assuming complete combustion, the theoretical equation for the formation of ceria with different fuels can be written as follows:

$\left(\mathrm{NH}_{4}\right)_{2} \mathrm{Ce}\left(\mathrm{NO}_{3}\right)_{6}$ (aq) $+(8 / 3) \mathrm{NH}_{2} \mathrm{CH}_{2} \mathrm{COOH}$ (aq) $\rightarrow$ $\mathrm{CeO}_{2}(\mathrm{~s})+(16 / 3) \mathrm{CO}_{2}(\mathrm{~g})+(32 / 3) \mathrm{H}_{2} \mathrm{O}(\mathrm{g})+(16 / 3) \mathrm{N}_{2}(\mathrm{~g})$

$\left(\mathrm{NH}_{4}\right)_{2} \mathrm{Ce}\left(\mathrm{NO}_{3}\right)_{6}(\mathrm{aq})+(4 / 3) \mathrm{C}_{6} \mathrm{H}_{8} \mathrm{O}_{7}(\mathrm{aq}) \rightarrow \mathrm{CeO}_{2}(\mathrm{~s})+8$ $\mathrm{CO}_{2}(\mathrm{~g})+(28 / 3) \mathrm{H}_{2} \mathrm{O}(\mathrm{g})+4 \mathrm{~N}_{2}(\mathrm{~g})$

$\left(\mathrm{NH}_{4}\right)_{2} \mathrm{Ce}\left(\mathrm{NO}_{3}\right)_{6}(\mathrm{aq})+(4 / 3) \mathrm{NH}_{2} \mathrm{CH}_{2} \mathrm{COOH}(\mathrm{aq})+(2 / 3)$ $\mathrm{C}_{6} \mathrm{H}_{8} \mathrm{O}_{7}$ (aq) $\rightarrow \mathrm{CeO}_{2}$ (s) $+(20 / 3) \mathrm{CO}_{2}(\mathrm{~g})+10 \mathrm{H}_{2} \mathrm{O}(\mathrm{g})+$ $(14 / 3) \mathrm{N}_{2}(\mathrm{~g})$

In this experiment the aqueous solution is prepared by disolving the proper amount of CAN (lobachemie, >99.5\%) and fuel (Merck, >99.7\%) in distilled water. The solution is stirred using magnetic stirrer for $2 \mathrm{~h}$. The resulting stirred solution is evaporated in small portions $(\sim 200 \mathrm{ml}$, producing 5 g powder) in a tall beaker (approximately 20 $\mathrm{cm}$ tall) on an electrical heater at $225^{\circ} \mathrm{C}$, during which it boils, foams and undergoes smoldering (flameless) combustion to produce the corresponding oxides. After completion of reaction it is observed that the powders are well contained within the beaker. However enough care is taken to ensure that the batches are sufficiently small to avoid an unmanageable reaction, both for safety reasons and also to ensure a homogeneous reaction. The resulting fine powders are calcined at $500^{\circ} \mathrm{C}$ for $2 \mathrm{hrs}$ in muffle furnace.

\subsection{XRD}

All the X-ray diffraction (XRD) experiments are carried out in a XRD machine (Phillips), using $40 \mathrm{kV}$ voltage, 30 $\mathrm{mA}$ current, $0.2 \mathrm{~mm}$ receiving slit, scintillation counter detector and $\mathrm{Cu} \mathrm{K \alpha}$ radiation. But no monochromator is attached with this system.

\subsection{Microstructural Characterization}

The powders have been examined using a field emission scanning electron microscopy FESEM (ZEISS) operating at $5.0 \mathrm{kV}$ attached with an energy dispersive X-ray spectrometer (EDS).

A high resolution transmission electron microscope (HRTEM) (JEOL 2010F) operating at $200 \mathrm{kV}$ is used to find the crystallite size of the ceria powder. The ceria powder is dispersed in acetone and the solution is kept in an ultrasonic vibrator for 1 hour. The solution is then allowed to settle down for $2 \mathrm{~min}$ and a drop of the solution is taken from the top layer and dropped on a carbon coated grid followed by drying at room temperature.

\section{Results and Discussion}

Figure 1 shows the XRD patterns of the ceria powder produced by $10 \mathrm{~h}$ ball milling and combustion synthesis. The broadening of peaks in the XRD patterns is due to three factors, i.e., instrumental error, lattice strain and nano-sized crystallite. In order to determine the crystallite size, the instrumental line broadening of the measured profiles is corrected using a $\mathrm{Si}$ (111) single crystal (PW3132/62) disc (32 mm diameter and $2 \mathrm{~mm}$ thick) as the standard sample. The structural broadening only due to crystallite size and lattice strain $\left(B_{(\text {struct })}\right)$ is obtained using the following equation:

$$
B_{(\text {struct })}=\sqrt{B_{o b s}^{2}-B_{s t d}^{2}}
$$

where, $B_{s t d}$ and $B_{o b s}$ are full width at half-maximum of any particular reflection from the standard sample (silicon disc) and the sample, respectively.

The analysis has been done by Williamson-Hall method [10]. In this method it is assumed that both size and strain broadened profiles are Lorentzian. Based on this assumption, a mathematical relation is established between the integral breadth $(\beta)$, volume weighted average crystallite size $\left(D_{v}\right)$ and the lattice strain $(\varepsilon)$ as follows.

$$
\frac{\beta \cos \theta}{\lambda}=\frac{1}{D_{v}}+2 \varepsilon\left(\frac{2 \sin \theta}{\lambda}\right)
$$

The plot of $\left(\frac{\beta \cos \theta}{\lambda}\right)$ versus $\left(\frac{2 \sin \theta}{\lambda}\right)$ gives the value of the lattice strains from the slope and crystallite size

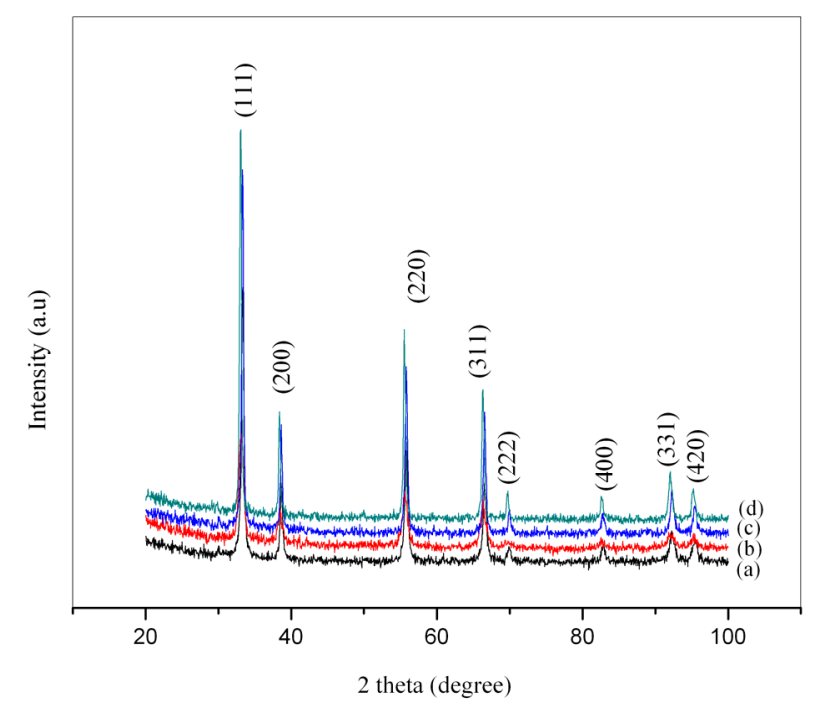

Figure 1. XRD patterns of (a) ceria powders produced by 10 h ball milling, (b) CAN + citric acid, (c) CAN + glycine and (d) CAN + citric acid + glycine. 
from the ordinate intercept.

The average crystallite size and lattice strain of ceria powder produced by different routes are calculated from the x-ray diffractograms and represented in Figure 2. It is observed that for ball milled ceria the crystallite size $(42 \mathrm{~nm})$ and lattice strain $\left(13.35 \times 10^{-4}\right)$ are larger than the crystallite size and lattice strain of ceria produced by the other routes. But minimum crystallite size $(17 \mathrm{~nm})$ and lattice strain $\left(2.58 \times 10^{-4}\right)$ are observed for ceria powder produced by combustion synthesis of solution containing CAN and citric acid. There is not any significant change in crystallite size and lattice strain of ceria powder produced by combustion synthesis of either CAN and glycine or CAN, glycine and citric acid.

The surface morphology of the ceria powders produced by different synthesis routes is studied using FE-

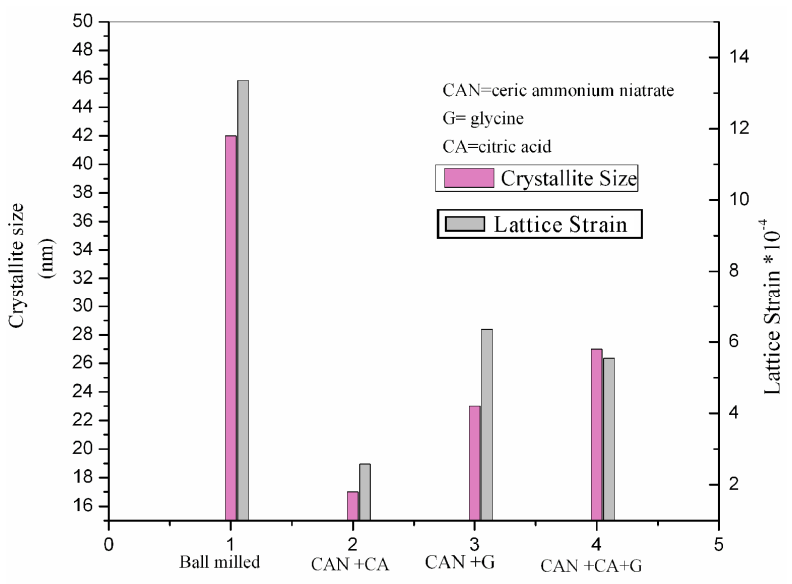

Figure 2. The crystallite size and lattice strain of ceria powders produced by different routes.

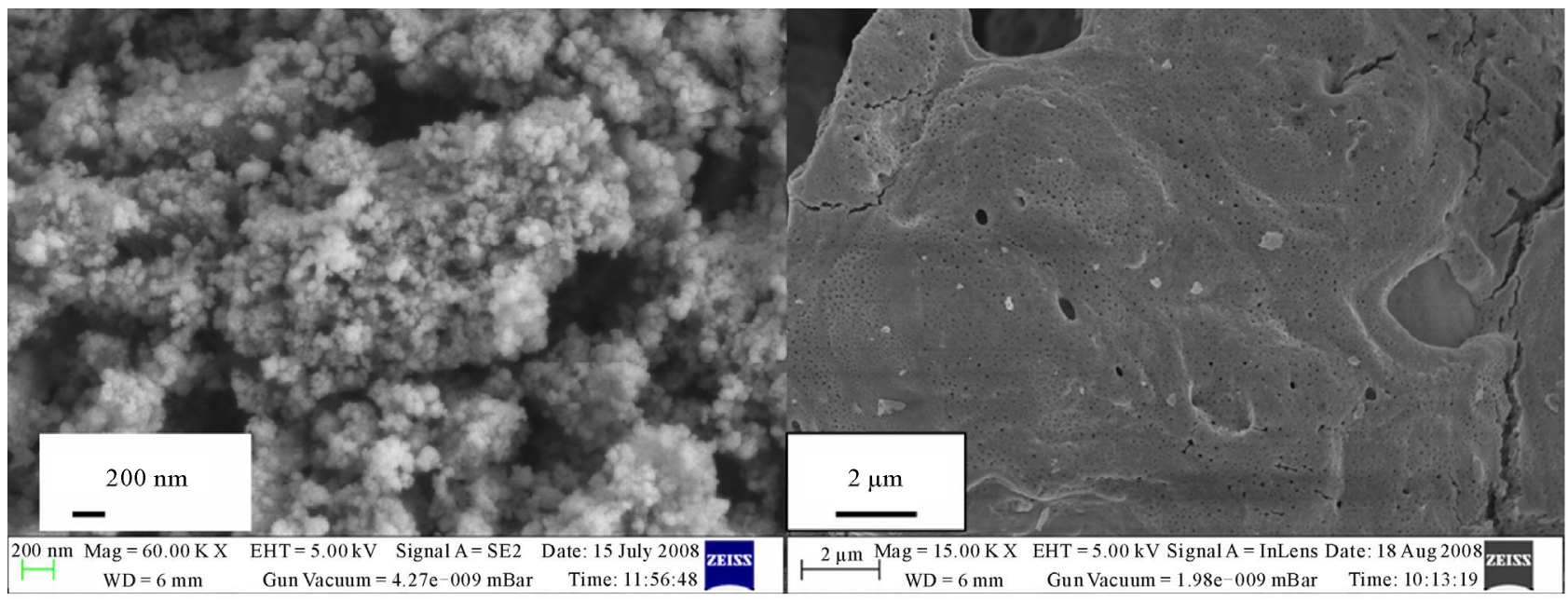

(a)

(b)

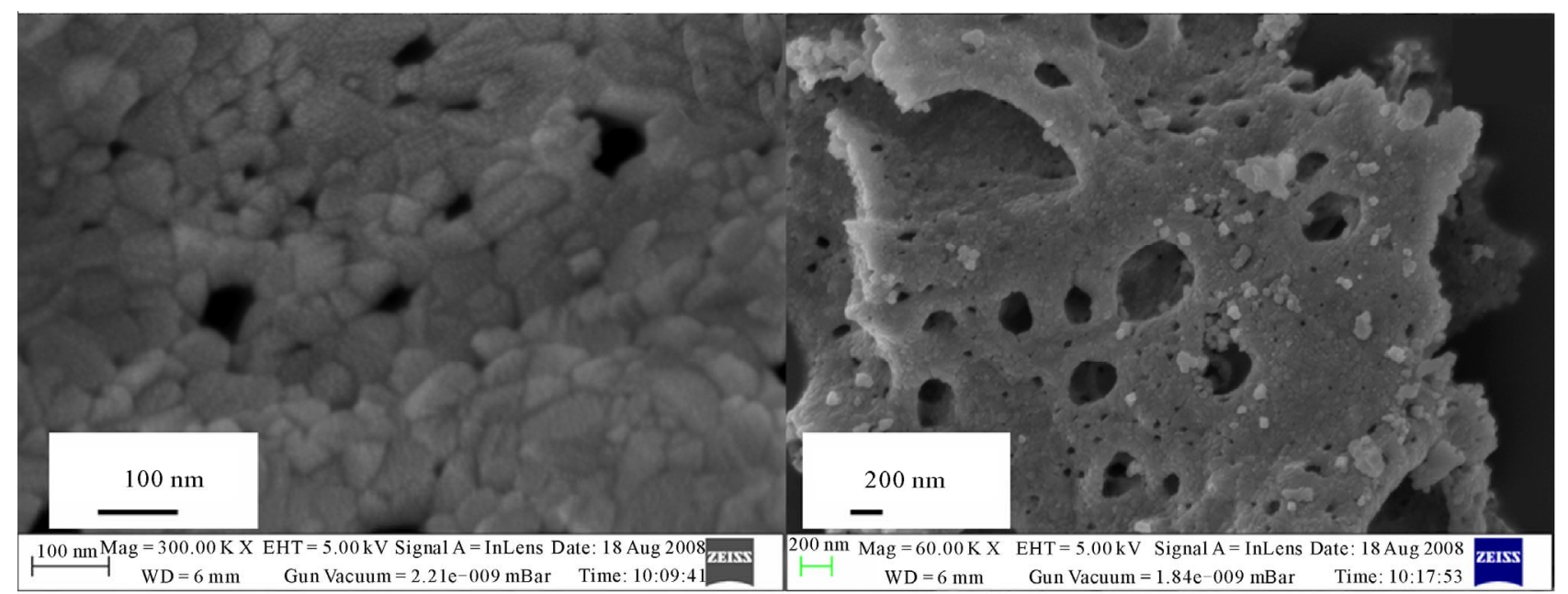

(c)

(d)

Figure 3. FESEM micrograph of ceria powder prepared by a) $10 \mathrm{~h}$ ball milling and combustion synthesis containing; b) CAN and citric acid, c) CAN and glycine and d) CAN, citric acid and glycine. 
SEM. Figure 3 shows the FESEM micrograph of ceria powder prepared by ball milling and combustion synthesis routes. From Figure 3 it is clear that the ceria powder produced by combustion synthesis has large number of porosity, but ball milled ceria powder is free from porosity. The ceria powder produced by mixed fuel process has larger size of porosity (micro meter) compared to the same produced by using citric acid or glycine as fuel.

Figure 4 shows the HRTEM results of ceria powder prepared by ball milling and combustion synthesis. The nanocrystalline nature of the ceria powder is further con- firmed by this HRTEM examination. From Figure 4 it is observed that the size distribution of the ceria powder particles produced by 1) ball milling technique varies from 30 to $50 \mathrm{~nm}$, and combustion synthesis containing 2) $\mathrm{CAN}$ and citric acid varies from 10 to $20 \mathrm{~nm}, 3$ ) CAN and glycine varies from 28 to $38 \mathrm{~nm}$ and (d) CAN, citric acid and glycine varies from 25 to $35 \mathrm{~nm}$. Ceria powder produced from combustion synthesis containing CAN and citric acid has lower particle size than the ceria powder produced by other routes. But on the contrary ceria powder produced from combustion synthesis

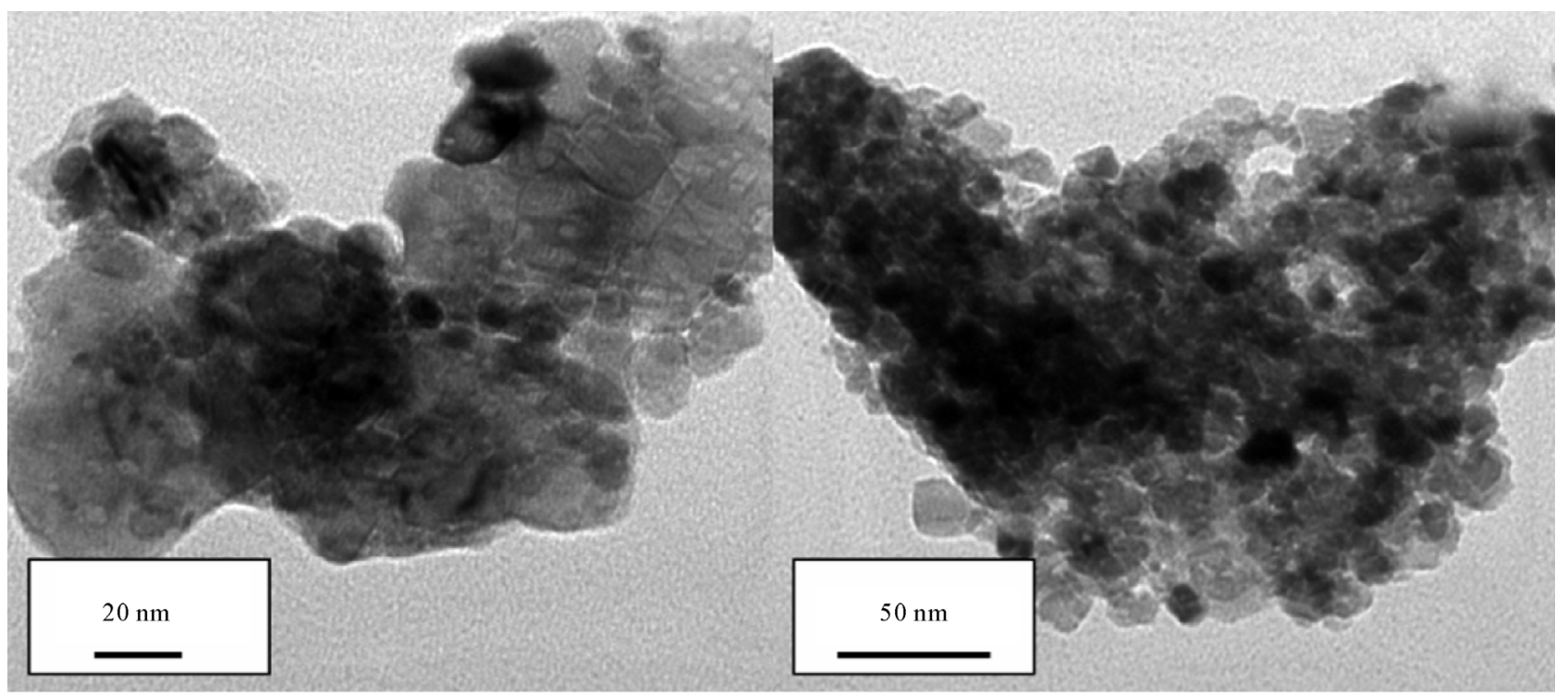

(a)

(b)

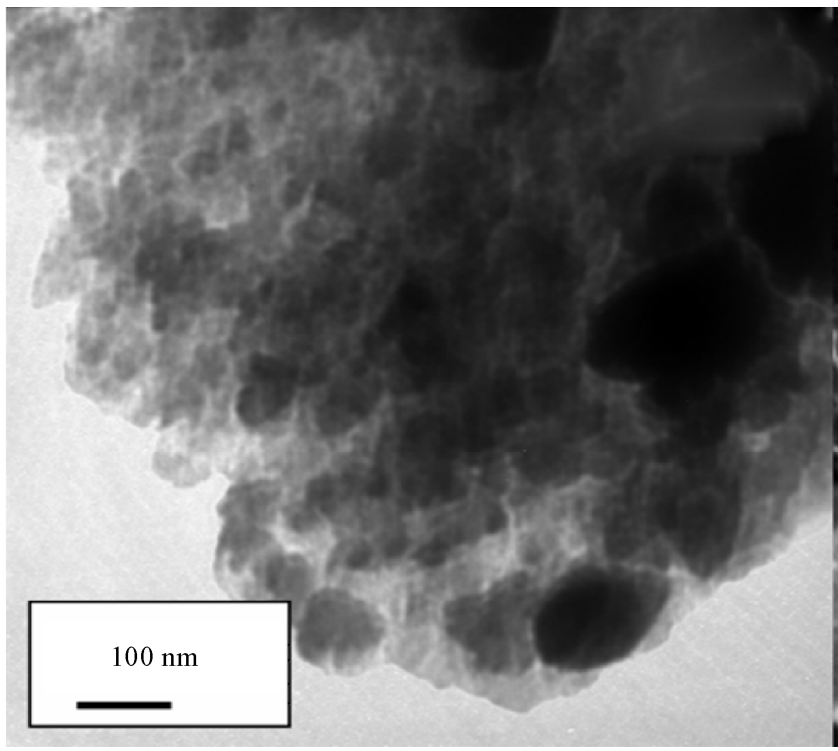

(c)

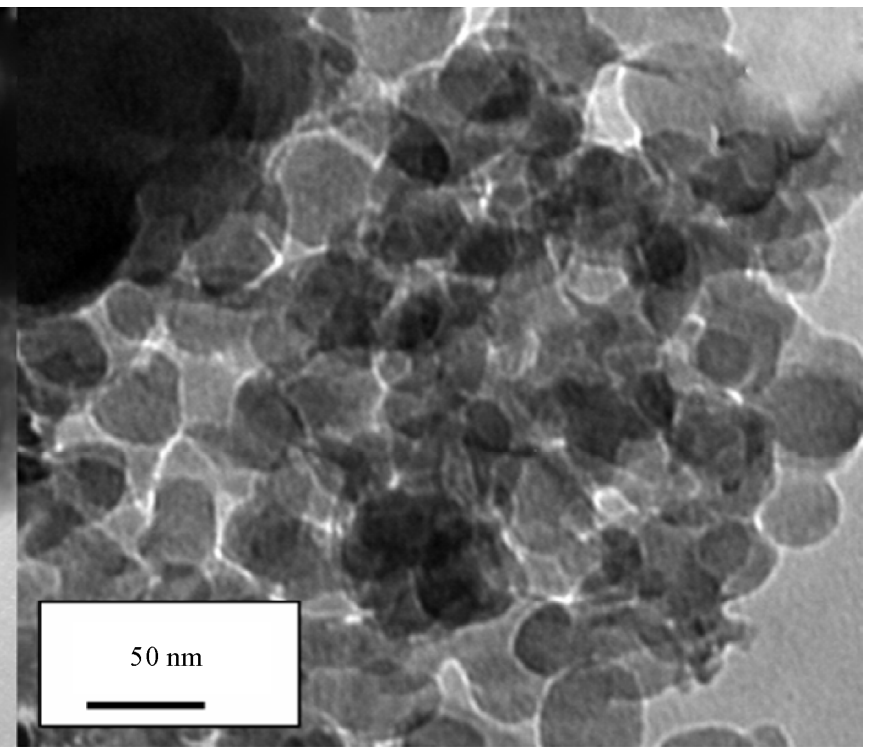

(d)

Figure 4. HRTEM micrograph of ceria powder prepared by a) 10h ball milling, and combustion synthesis containing b) CAN and citric acid, c) CAN and glycine and d) CAN, citric acid and glycine. 
containing CAN and citric acid and glycine has less agglomeration of particles than other techniques.

\section{Conclusions}

- The nanosized ceria powder can be produced by high energy ball milling and combustion synthesis techniques.

- From XRD it is found that the crystallite size (42 $\mathrm{nm})$ and lattice strain $\left(13.35 \times 10^{-4}\right)$ of ball milled ceria are larger than the crystallite size and lattice strain of ceria produced by the combustion synthesis technique. Minimum crystallite size $(17 \mathrm{~nm})$ and lattice strain $\left(2.58 \times 10^{-4}\right)$ are observed for ceria powder produced by combustion synthesis of CAN and citric acid.

- TEM analysis shows that the particles of ceria powder are uniformly distributed or less agglomerated in the mixed fuel process.

- FESEM study reveals that the ceria powder produced by combustion synthesis has large number of porosity, but ball milled ceria powder is free from porosity.

\section{REFERENCES}

[1] J. Sergeant and A. Bakhshai, "Nano-Composites and Mechanical Alloying via the Ball Milling Technique," Proceedings of the National Conference on Undergraduate Research (NCUR) 2006, University of North Carolina Ashville, Ashville, 6-8 April 2006.

[2] W. Zhu, O. K. Tan and J. Z. Jiang, "A New Model and Gas Sensitivity of Non-Equilibrium $\mathrm{xSnO}_{2}-(1-\mathrm{x}) \alpha-\mathrm{Fe}_{2} \mathrm{O}_{3}$ Nano-Powders Prepared by Mechanical Alloying," Journal of Materials Science: Materials in Electronics, Vol. 9, 1998, pp. 275-278. doi:10.1023/A:1008820605197

[3] W. Cao, O. K. Tan, W. Zhu, B. Jiang and C. V. G. Reddy,
"An Amorphous-Like $\mathrm{x} \alpha-\mathrm{Fe}_{2} \mathrm{O}_{3}-(1-\mathrm{x}) \mathrm{ZrO}_{2}$ Solid Solution System for Low Temperature Resistive-Type Oxygen Sensing," Sensors and Actuators B: Chemical, Vol. 77, No. 1-2, 2001, pp. 421-426. doi:10.1016/S0925-4005(01)00748-1

[4] O. K. Tan, W. Cao, W. Zhu, J. W. Chai and J. S. Pan, "Ethanol Sensors Based on Nano-Sized $\alpha-\mathrm{Fe}_{2} \mathrm{O}_{3}$ with $\mathrm{SnO}_{2}, \mathrm{ZrO}_{2}, \mathrm{TiO}_{2}$ Solid Solutions," Sensors and Actuators B: Chemical, Vol. 93, No. 1-3, 2003, pp. 396-401. doi:10.1016/S0925-4005(03)00191-6

[5] C. V. G. Reddy, W. Cao, O. K. Tan, W. Zhu and S. A. Akbar, "Preparation of $\mathrm{Fe}_{2} \mathrm{O}_{3(0.9)}-\mathrm{SnO}_{2(0.1)}$ by Hydrazine Method: Application as an Alcohol Sensor," Sensors and Actuators B: Chemical, Vol. 94, No. 1, 2003, pp. 99-102.

[6] L. B. Kong, W. Zhu and O. K. Tan, "Preparation and Characterization of $\mathrm{Pb}\left(\mathrm{Zr}_{0.52} \mathrm{Ti}_{0.48}\right) \mathrm{O}_{3}$ Ceramics from High-Energy Ball Milling Powders," Materials Letters, Vol. 42, No. 4, 2000, pp. 232-239. doi:10.1016/S0167-577X(99)00190-1

[7] Y. Hu, O. K. Tan, J. S. Pan and X. Yao, “A New Form of Nanosized $\mathrm{SrTiO}_{3}$ Material for Near-Human-Body Temperature Oxygen Sensing Applications," The Journal of Physical Chemistry B, Vol. 108, No. 26, 2004, pp. 1121411218. doi:10.1021/jp048973z

[8] Y. Kanno, "Properties of $\mathrm{SiC}, \mathrm{Si}_{3} \mathrm{~N}_{4}$ and $\mathrm{SaO}_{2}$ Ceramic Powders Produced by Vibration Ball Milling," Powder Technology, Vol. 44, No. 1, 1985, pp. 93-97. doi:10.1016/0032-5910(85)85027-0

[9] J. J. Moore and H. J. Feng, "Combustion Synthesis of Advanced Materials: Part I. Reaction Parameters," Progress in Materials Science, Vol. 39, No. 4-5, 1995, pp. 243-273. doi:10.1016/0079-6425(94)00011-5

[10] J. A. Pask, X. W. Zhang, A. P. Tomsia and B. E. Yoldas, "Effect of Sol-Gel Mixing on Mullite Microstructure and Phase Equilibria in the $\alpha-\mathrm{Al}_{2} \mathrm{O}_{3}-\mathrm{SiO}_{2}$ System,' Journal of the American Ceramic Society, Vol. 70, No. 10, 1987, pp. 704-707. doi:10.1111/j.1151-2916.1987.tb04867.x 